\title{
RNA-Binding Protein 14
}

National Cancer Institute

\section{Source}

National Cancer Institute. RNA-Binding Protein 14. NCI Thesaurus. Code C114450.

RNA-binding protein 14 (669 aa, $\sim 69 \mathrm{kDa}$ ) is encoded by the human RBM14 gene. This protein plays a role in the modulation of gene expression. 